\title{
The Impact of Capital Adequacy and Operational Costs on Operational Revenues (BOPO) on Operating Profit
}

\author{
Gede Putu Agus Jana Susila ${ }^{1, *}$ I Wayan Cipta ${ }^{1}$ Ni Luh Wayan Sayang Telagawathi ${ }^{1}$ \\ Gede Wira Kusuma ${ }^{1}$ \\ ${ }^{1}$ Department of Management, Universitas Pendidikan Ganesha, Singaraja, Indonesia \\ "Corresponding author. Email: agus.jana@undiksha.ac.id
}

\begin{abstract}
This study was conducted to examine the effect of capital adequacy and operational costs on operational revenues (BOPO) on operating profit simultaneously or partially. This study was classified as causal quantitative study. The subjects of this study consisted of Village-Owned Enterprises in Banjar Sub-District, which were registered at the Village and Community Empowerment Service, and the objects included capital adequacy, operational costs, operational revenues and operating profit. The samples that were involved in this study were determined by means of purposive sampling with a total sample of six BUMDes. Moreover, data were gathered by means of document recording, and were then analyzed by using multiple linear regression analysis. The results showed that (1) capital adequacy and operational costs on operational revenues provided a significant effect on operating profit (2) capital adequacy provided a negative and insignificant effect on operating profit (3) operational costs on operational revenues had a negative and significant effect on operating profit. Keywords: capital adequacy, operational costs on operational revenues, and operating profit.
\end{abstract}

Keywords: Capital Adequacy, Operational Costs on Operational Revenues, Operating Profit.

\section{INTRODUCTION}

Village-Owned Enterprises (here in after referred to as BUMDes) are village business entities or microfinance institutions that specifically aim to manage and regulate village financial management. BUMDes are operationally supported by village monetary institutions that contribute to conducting financial transactions in the form of credit and public savings [1]. Since Law No. 6 of 2014 concerning villages has been successfully implemented by the government, BUMDes has a crucial role in stimulating rural community income by providing savings and loan unit services as access to capital for rural communities. In Bali area, only a few villages are known to form BUMDes, but the number of existing BUMDes has been growing after some time. This is indicated by data on the number of villages in Bali, which amounted to 636, which declared that 455 BUMDes had been formed since the beginning of 2018 [2]. As one of the village financial institutions, BUMDes is always associated with its main objective, particularly to earn a profit. A business entity is specifically established to earn a profit [3].

Profit is referred to one of the important issues that should be achieved by a business being run. Profit is earned from operating activities carried out by a company and shows the level of efficiency in its management performance. To achieve the internal goals of a company, operating profit is defined as an accounting measure of profit generated from operating activities carried out by the company and is calculated before being deducted by taxes and interest [4]. A business entity should be managed professionally to prevent any losses and be able to obtain targeted profits. Optimal profit gain is able to show the level of efficiency of financial institutions in carrying out their operational activities.

Profit or profitability is capable of being used to measure the soundness of a bank which is influenced by financial ratios such as the Capital Adequacy Ratio (CAR), Non-Performing Loan (NPL), Operational Costs on Operational Revenues (locally known as BOPO) and Net Interest Margin (NIM) [5]. This study was more focused on using capital adequacy and BOPO variables that can affect the operating profit in a financial institution. The capital adequacy of a company is able to result in the higher ability of financial institutions to finance their operations, which will subsequently cause profits to increase [6]. Moreover, the lower the operational costs compared to operational revenues, the higher the company's profit. Thus, a high capital adequacy and a 
lower BOPO ratio will cause profits or profitability to increase.

First, operating profit in a BUMDes is assumed to be influenced by capital adequacy. Capital adequacy is defined as a ratio in a financial institution used to measure management's performance and ability to finance operational activities and bear all risks encountered in its assets [7]. The high capital adequacy will cause the company to be more capable in financing its operations and in achieving favorable conditions, thus leading to increased profit. This statement is supported by a study conducted by Saputra and Budiasih, which stated that the capital adequacy ratio was partially able to provide a positive influence on the profitability of banks listed on the IDX in 2009-2013 [8]. Another study conducted by Mukaramoh and Supriono also stated that CAR had a positive and significant effect on profitability (ROA)[9]. However, it is conversely different from the study conducted by Prasetyo and Darmayanti, which stated that capital adequacy had an insignificant negative effect on profitability [10].

Second, operating profit in a BUMDes is assumed to be influenced by BOPO. BOPO ratio is commonly known as the ratio between costs and operational revenues, which is used to measure the performance of management and the ability of company to carry out its operational activities, specifically the ability to control high operational costs and obtain high operational revenues [7]. The lower the BOPO ratio, the more efficient the management performance in financial institutions, which will further increase the company's profit or profitability. Conversely, the higher BOPO ratio will be able to show that the operational costs incurred are greater than the revenues earned, thus leading to lower profits. This statement is supported by a study conducted by Saputra and Budiasih, which stated that BOPO had a negative effect on the profitability of banks listed on the IDX in 2009-2013 [8]. Another study was also conducted by Parasdita, et al, which stated that BOPO provided a negative effect on profitability [11]. It was in line with the study conducted by Mukaromah and Supriono, which stated that operational efficiency (BOPO) had a highly positive and significant effect on profits or profitability [9].

This study was conducted due to inconsistencies in the results of previous studies regarding to factors that affect profits or profitability in financial institutions, such as capital adequacy and BOPO. In addition, the gap was likely found between the theory which state that the higher the capital adequacy ratio and the lower the BOPO ratio can increase profits or profitability, which was evidenced by the facts of problems that tend to be encountered in the field.

BUMDes in Banjar Sub-District were successfully determined as the subjects of this study, because BUMDes in Banjar Sub-District tend to operate actively and experience fluctuations in their profits. A good financial institution can be measured by its ability to get maximum profit. Profit fluctuations generated in each period indicate that the financial institution is in a bad condition and will affect operational activities in the future. The BUMDes of the Banjar Sub-district registered at the Buleleng Regency Community and Village Empowerment Office until 2019 was amounted to 15 BUMDes. However, only 6 of the 15 BUMDes which were actively operating and had complete financial reports from 2015-2019. There were three BUMDes that experienced fluctuations in operating profit in each period.

Several problems regarding to the capital adequacy and BOPO on operating profit at BUMDes in Banjar SubDistrict were likely to be encountered. BUMDes Tunas Kertha in 2017 showed an increase in capital adequacy by $5 \%$, from $1.02 \%$ in 2016 to $1.05 \%$ in 2017 . In 2019 , there was an increase in capital adequacy of $0.96 \%$, from $1.04 \%$ in 2018 to $1.05 \%$ in 2019. A similar increase was also shown by BUMDes Banyu Ayu Mandara in 2016 of $4.54 \%$, from $1.10 \%$ in 2015 to $1.15 \%$ in 2016 , and in 2018 , there was increased capital adequacy by $2.91 \%$, from $1.03 \%$ in 2017 to $1.06 \%$ in 2018. Furthermore, BUMDes Adil Sejahtera also indicated an increase in capital adequacy in 2019 of $153.06 \%$, from $0.49 \%$ in 2018 to $1.24 \%$ in 2019 . However, the increase in capital adequacy in these three BUMDes was not followed by an increase in operating profit. This is not in accordance with the theory put forward by Dendawijaya, which states that higher capital adequacy or CAR is able to increase profits [7].

BUMDes Tunas Kertha in 2017 showed a decrease in the BOPO ratio by $0.54 \%$, from $60.75 \%$ in 2016 to $60.42 \%$ in 2017. A similar decrease also occurred in BUMDes Banyu Ayu Mandara in 2019 by $0.72 \%$, from $85.58 \%$ in 2018 to $84.96 \%$ in 2019 . Moreover, BUMDes Adil Sejahtera in 2018 also indicated an increase in the BOPO ratio of $7.38 \%$, from $62.84 \%$ in 2017 to $67.48 \%$ in 2018. However, the decrease in the BOPO ratio in two BUMDes and the increase in the BOPO ratio in one BUMDes were not followed by an increase and decrease in operating profit. This is not in accordance with the theory stated by Dendawijaya, which states that the decreasing BOPO ratio is capable of increasing the efficiency of the company, thus leading to the increased profit [7]. On the other hand, the higher BOPO ratio indicates the higher operational costs incurred by financial institutions, thus resulting in lower operating profit. This study was intended to examine the impact of capital adequacy and BOPO on operating profit, capital adequacy on operating profit, and BOPO on operating profit at BUMDes in Banjar Sub-District.

\section{LITERATUR REVIEW}

\subsection{Operating Profit}

Operating profit is the profit of a company derived from the main activities or the results obtained from the 
company's operational activities [12]. To achieve the internal goals of a company, operating profit is defined as an accounting measure of profit generated from operating activities carried out by the company and is calculated before being deducted by taxes and interest [4]. Profit is referred to as the difference between the revenues earned and the costs that must be incurred by the company to finance its operations. The indicator used to measure operating profit is revenue minus profit, namely: Operating Profit $=$ Revenue - Costs. The level of efficiency and soundness of financial institutions can be measured from the profits or profitability obtained, and can be influenced by financial ratios. Two factors that affect profit or profitability consist of the capital adequacy ratio and the BOPO ratio [5].

\subsection{Capital Adequacy}

Capital adequacy is a ratio that compares the amount of capital with a number of assets owned by banking companies or financial institutions [13]. The measurement indicators consist of capital and RWA. Referring to Bank Indonesia Regulation No. 10/15/PBI/2008 Article 2, Banks are required to provide a minimum of $8 \%$ of Risk Weighted Assets (RWA). A bank or financial institution that is unable to provide a minimum capital of $8 \%$ will tend to experience the loss of capital to interested parties. Capital Adequacy Ratio (CAR) is a ratio to measure the performance and ability of a financial institution to finance its operations and to bear all risks that may arise on its assets [7]. The formula that can be used to measure the capital adequacy of a banking institution is:

$$
\mathrm{CAR}=\frac{\text { Capital }}{\text { Risk Weighted Assets (RWA) }}
$$

\subsection{Operational Costs on Operational Revenues}

BOPO is defined as the ratio between operational costs and operational revenues which is used to measure the level of efficiency or performance of a company and the ability of the company, particularly in performing its operational activities [7]. A company with a high ratio indicates the inability to operate accordingly. Based on Bank Indonesia Circular No.15/7/DPNP/ dated March 8, 2013, the BOPO ratio scale is expressed in percent (\%). The BOPO ratio owned by a financial institution should be $<85 \%$, if it exceeds $85 \%$, then the Bank Indonesia criteria cannot be met by the BOPO. The indicators of BOPO consist of Operational Costs and Operational Revenues [7]. The efficiency of the company in performing its operating activities can be determined by calculating the ratio between Operational Costs and Operational Revenues through the following formula.

$\mathrm{BOPO}=\frac{\text { Operational Costs }}{\text { Operational Revenues }} \times 100 \%$

\section{METHOD}

This study was conducted in bumdes located in Banjar sub-district. This study used a causal quantitative design to obtain information regarding to the effect of BOPO and capital adequacy on operating profit at BUMDes in Banjar sub-district. The subjects involved in this study consisted of BUMDes in Banjar sub-district. Furthermore, the object of this study included capital adequacy, BOPO, and operating profit. BUMDes in Banjar sub-district were determined as the study population with a total of 15 BUMDes. In addition, the samples in this study were successfully determined by means of a purposive sampling technique with criteria for BUMDes that had been established and had been operating actively from 2015 - 2019 and had a complete balance sheet and revenue statement, which was amounted to six BUMDes. Data on this study were collected through document recording. Data collection process was carried out by recording the BUMDes annual financial report. The data were comprised of balance sheet and profit and loss financial statements at BUMDes in Banjar sub-district. Subsequently, the data were analyzed by utilizing multiple linear regression analysis. Prior to data analysis using multiple linear regression analysis, the classical assumption test should be initially conducted, because the data can only be analyzed by multiple linear regression without being accompanied by a classical assumption test. The hypotheses of this study:

H1: There is an effect of capital adequacy and BOPO on operating profit at BUMDes in Banjar sub-district

$\mathrm{H} 2$ : There is an effect of capital adequacy on operating profit at BUMDes in Banjar sub-district

H3: There is an effect of BOPO on BUMDes in Banjar sub-district.

\section{RESULT \& DISCUSSION}

\subsection{Result Research}

This analysis was carried out using the SPSS 22.0 for Windows program. The test results obtained from the SPSS output (Summary) are presented in Table 1. The structure of the relationship between the effects of Capital Adequacy $\left(\mathrm{X}_{1}\right)$ and BOPO $\left(\mathrm{X}_{2}\right)$ on Operating Profit $(\mathrm{Y})$ is shown in Figure 1. 
Table 1. Summary of SPSS Output Results

\begin{tabular}{|l|l|c|l|l|}
\hline Parameter & Nilai & P-Value & Alpha & Keputusan \\
\hline Ryx ${ }_{1} x_{2}$ & 0,679 & 0,000 & 0,05 & Menolak $\mathrm{H}_{\circ}$ \\
\hline$R^{2} \mathrm{yx}_{1} \mathrm{x}_{2}$ & 0,462 & - & - & - \\
\hline Pyx $1_{1}$ & $-0,056$ & 0,774 & 0,05 & Menerima $\mathrm{H}_{\mathrm{o}}$ \\
\hline $\mathrm{P}^{2} \mathrm{yx}_{1}$ & 0,003 & & - & - \\
\hline Pyx $_{2}$ & $-0,679$ & 0,000 & 0,05 & Menolak $\mathrm{H}_{\circ}$ \\
\hline $\mathrm{P}^{2} \mathrm{yx}_{2}$ & 0,461 & - & - & - \\
\hline$\varepsilon$ & 0,538 & - & - & - \\
\hline
\end{tabular}

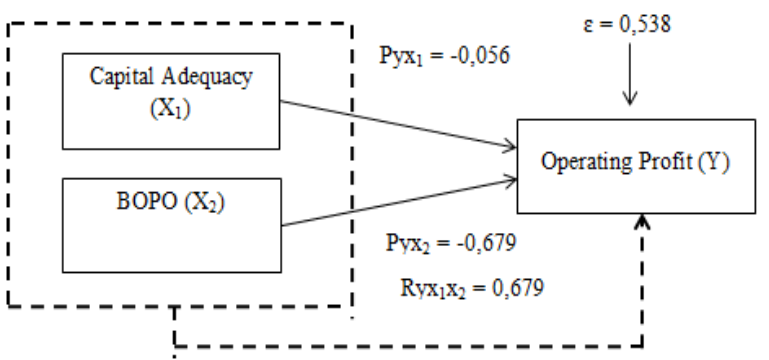

Figure 1. Structure of the Relationship between the Effects of Capital Adequacy and BOPO on Operating Profit

The results of multiple linear regression as shown in Table 1. indicated the constant value $(\alpha)$ of 119.089.011,217; capital adequacy regression coefficient $\left(\beta_{1}\right)$ of $-50.249,380$; BOPO regression coefficient value $\left(\beta_{2}\right)$ of $-962.818,107$; and $\varepsilon$ of 0,538 . Therefore, the regression equation may be formulated as $\mathrm{Y}=$ $119.089 .011,217+-50.249,380 X_{1}+-962.818,107 X_{2}+$ 0,538 . Moreover, the results of multiple linear regression indicated that (1) The constant was amounted to 119.089.011,217. Consequently, if the capital adequacy $\left(\mathrm{X}_{1}\right)$ and BOPO $\left(\mathrm{X}_{2}\right)$ value was equal to zero, then the operating profit (Y) was amounted to 119.089.011,217. (2) The value of the capital adequacy coefficient $\left(\beta_{1}\right)$ was amounted to $-50.249,380$, and provided a negative effect on operating profit $(\mathrm{Y})$. This showed that every increase in capital adequacy $\left(\mathrm{X}_{1}\right)$ one unit was able to reduce the value of operating profit (Y) by $50.249,380$ with the assumption that the other independent variables were constant. (3) The value of the BOPO coefficient $\left(\beta_{2}\right)$ of $962.818,107$ had a negative effect on operating profit (Y). This indicated that for every increase in BOPO $\left(\mathrm{X}_{2}\right)$ one unit was able to reduce the value of operating profit $(\mathrm{Y})$ 611.091,208 with the assumption that the other independent variables were constant. In addition, the results of the coefficient of determination $\left(\mathrm{R}^{2}\right)$ in this study provided a value of 0,462 which indicated the influence of the independent variable on the dependent variable of $46.2 \%$. While the rest was influenced by other variables that were not examined in the linear regression model.

\subsection{Discussion}

The first hypothesis of the study is the effect of Capital Adequacy $\left(\mathrm{X}_{1}\right)$ and BOPO $\left(\mathrm{X}_{2}\right)$ on Operating Profit (Y) at BUMDes in Banjar Sub-District. Having regard to the results of multiple linear regression, the results of $\mathrm{Ryx}_{1} \mathrm{x}_{2}$ were found to be 0.679 , which means $\neq 0$ with $p$-value of $0.000<$ alpha $(\alpha)(0.05)$. Based on this result, Ho was rejected, which indicated that capital adequacy and BOPO provided a significant effect on operating profit. Moreover, $\mathrm{R}^{2} \mathrm{yx}_{1} \mathrm{x}_{2}$ showed the contribution of the simultaneous effect of capital adequacy and BOPO on operating profit, which was only amounted to 0.462 . These results clearly showed that operating profit was only provided with an influence of $46.2 \%$ by the variables of capital adequacy and BOPO. While the influence of variables outside of capital adequacy and BOPO was amounted to $53.8 \%$. This indicated that the variables of capital adequacy and BOPO simultaneously contributed to the increase in operating profit. Therefore, the first hypothesis was accepted. The results of this study are in line with the theory proposed by Suhardjono and Kuncoro, which stated that a high capital adequacy is capable of strengthening the financial institution in financing its operations, and can cover the company's losses, which subsequently able to provide a significant influence to profit or profitability[6]. In this specific matter, the company is required to reduce its operational costs. Moreover, a low BOPO ratio will lead to increasing profits. Consequently, it may be inferred that higher capital adequacy and lower BOPO ratios are able to increase the efficiency of financial performance within the company, which will further have an effect on increasing profits or profitability of financial institutions. The results of this study are also in line with the results of the study conducted by Ginting Suriani which found that Capital Adequacy and BOPO simultaneously contributed to the effect of Profit Growth in Banking Companies Listed on the Indonesia Stock Exchange for the Period of 2013 2016 [14].

The second hypothesis of this study is the effect of capital adequacy on operating profit at BUMDes in Banjar Sub-District. Multiple linear regression test indicated the results of $\mathrm{Pyx}_{1}=-0.056 \neq 0$ with p-value $(0.774)>$ alpha $(\alpha)(0.05)$. Referring to the result, Ho was then accepted, which indicated that capital adequacy had a negative and insignificant effect on operating profit. This finding also implied that capital adequacy did not contribute any significant role to increase operating profit with an effect of $-5.6 \%$ and $\mathrm{P}^{2} \mathrm{yx}_{1}$ which showed a large contribution of $0.3 \%$. Therefore, it may be concluded that capital adequacy had a partial negative and insignificant effect on operating profit at BUMDes in Banjar Sub-District. Referring to that, the second hypothesis was accepted. The results of this study indicated that high capital adequacy was capable of having an impact on a decrease in operating profit. This is also considered inconsistent with the theory put forward by Dendawijaya, which states 
that a higher CAR value will be able to increase profits, because financial institutions are able to finance operations and are in favorable conditions if provided by high capital [7]. In relation to capital adequacy, the more capital owned, the greater the opportunity to operate, which will further affect the increase in operating profit. In this study, high capital adequacy was considered not necessarily able to guarantee an increase in profits obtained by BUMDes, due to the inefficiency of management performance in allocating owned capital, particularly for loans disbursed and for purchasing company fixed assets, and inefficient use to finance its operational activities, thus leading to expenditure on operational costs that were greater than operational revenues. This also required greater capital to be used to finance its operational activities and finance highly risky assets. The negative capital adequacy coefficient indicated a non-unidirectional relationship, which means that every increase in capital adequacy caused the resulting profit to decrease. This can be seen in the increase in capital adequacy that occurred in BUMDes Artha Sari Lestari from 2015 by $102.76 \%$, in 2016 to $105.85 \%$, in 2017 to $111.37 \%$, and also an increase in 2018 to in 2019 from $103.19 \%$ to $105.12 \%$. This increase in capital adequacy also led to a decrease in operating profit. The results of this study are supported by an empirical study conducted by Prasetyo and Darmayanti, which found that capital adequacy partially had no significant negative effect on profits or profitability [10].

The third hypothesis of this study is the effect of BOPO on operating profit at BUMDes in Banjar SubDistrict. Multiple linear regression test results showed $\mathrm{Pyx}_{2}$ value of $-0.679 \neq 0$ with $\mathrm{p}$-value $(0.000)<$ alpha $(\alpha)$ (0.05). Based on the result, Ho was then rejected, which indicated that a negative and significant effect was provided by BOPO on operating profit. This finding also implied that BOPO did not contribute any role in increasing operating profit with an effect of $-67.9 \%$, and $\mathrm{P}^{2} \mathrm{yx}_{2}$ showed a large contribution of $46.1 \%$. Consequently, it may be concluded that BOPO had a partially negative and significant effect on operating profit at BUMDes in Banjar Sub-District. Therefore, the third hypothesis was accepted. The results of this study are in line with the theory submitted by Dendawijaya which states that a lower BOPO ratio is capable of increasing profits, and a higher BOPO ratio is able to significantly reduce profits [7]. This shows that the efficiency of management performance in using the available resources for operational activities is increasing. Larger costs will be capable of resulting in smaller profits. Moreover, the acquisition of greater profits will further be less likely to be in a problematic condition, thus increasing profits or profitability. The negative BOPO coefficient indicated a non-unidirectional relationship between BOPO and operating profit, which means that every decrease in the BOPO ratio was accompanied by an increase in profit. Furthermore, every increase in the BOPO ratio was accompanied by a decrease in operating profit. This was also found in BUMDes Artha Sari Lestari which experienced an increase in BOPO consecutively in 2015 by $43.11 \%$, increased to $55.31 \%$ in 2016 , increased to $66.71 \%$ in 2017, increased to $78.41 \%$ in 2018, and in 2019 increased to $79.35 \%$. These increases in BOPO ratio caused a decrease in operating profit. The results of this study are supported by an empirical study carried out by Sudianto, et al, which found that Operational Efficiency (BOPO) partially contributed a negative and significant effect on profits at Regional Development Banks (BPD) in Eastern Indonesia in 2011-2015 [15].

The results in this study implied that capital adequacy provided a negative and insignificant effect on operating profit. This indicated that the higher capital adequacy was capable of decreasing the profits obtained from the operational results of the BUMDes. Regarding to this matter, capital adequacy was considered to have a very vital role in the development of the BUMDes. Consequently, when the capital owned by the financial institution is increasing, its ability to operate and finance its operational activities will also grow, which is further capable of generating influence on the large and small amount of operating profit obtained. However, in the results of this study, it was found that high capital adequacy had not been able to increase the profits earned by BUMDes. This showed that management was not likely to be effective in allocating its resources, specifically to finance its operational activities where the operational costs incurred were greater than the revenue generated, thus would also reduce the profit earned by the BUMDes. This study implied that capital adequacy did not provide any role in increasing operating profit with an influence of $-0.056 \%$ and a large contribution of $0.3 \%$. In addition, BOPO was found to have a negative and significant effect on operating profit. This showed that the lower BOPO ratio was not capable of increasing operating profit. This indicated that there was management inefficiency in managing its resources, and the lower ability of BUMDes management to reduce operational costs. This means that the operational costs incurred were greater than the operational revenues, thus the operating profit obtained was also lower. This study implied that BOPO did not provide any role in increasing operating profit with an influence of $-0.679 \%$ and a large contribution of influence of $46.1 \%$.

\section{CONCLUSION}

Based on the results of the study on BUMDes in Banjar Sub-District in 2015 - 2019, which have been described previously, it may be concluded that (1) Capital Adequacy and BOPO had a simultaneous significant effect on operating profit of BUMDes in Banjar SubDistrict; (2) Capital Adequacy had a negative and insignificant effect on operating profit at BUMDes in Banjar Sub-District. Moreover, BOPO provided a 
negative and significant effect on operating profit at BUMDes in Banjar Sub-District.

Based on several conclusions described earlier, BUMDes that have been registered with the Community and Village Empowerment Service are expected to be more capable of optimizing their capital, which can further be utilized efficiently in performing operational activities. Moreover, the credit distribution process and the smooth rate of repayment of these loans, as well as other assets that contain risks also need to be highly considered. In addition, BUMDes are also expected to be able to reduce operational costs in their operations, and be better able to optimize their operational revenues. Therefore, BUMDes will subsequently be able to optimize the profits to be obtained.

\section{REFERENCES}

[1] Faculty of Economic Brawijaya University, Ministry of National Education in the Center for the Stury of Development System Dynamics (PKDSP). Establishment and Management Guidebook BUMDes, 2007.

[2] "Bali Province Village and Community Empowerment Service," 2018.

[3] Kasmir, Banking Management Revised Edition. Jakarta:PT. Raja Grafindo Persada, 2015.

[4] M. Fuad, Introduction to Business. Jakarta:PT Gramedia Pustaka Utama, 2006.

[5] H. Iswi, Restructuring and Elimination of Bad Credit. Jakarta: PT Elex Media Komputindo, 2010.

[6] M. Kuncoro and Suhardjono, Banking Management Theory and Application. Jakarta: Penerbit BPFE, 2002.

[7] L. Dendawijaya, Banking Management Revised Edition. Bogor: Ghalia Indonesia, 2009.

[8] Saputra and I. G. A. N. Budiasih, "Effect of Capital Adequacy, Credit Risk, Operating Expenses of Operating Income on Bank Profitability," E-Jurnal Akunt. Univ. Udayana, vol. 14, no 3. ISSN: 23028559,2016

[9] Mukaramoh and Supriono, "Effect of Capitak Adequacy, Credit Risk, Operational Efficiency and Liquidity on The Profitability of Banks Listed on the Indonesia Stock Exchange in 2015-2017," J. Econ. Manag. Account. Technol., vol. 3, no 1. e-ISSN: 2622-8122, 2020.

[10] Prasetyo and Darmayanto, "Effect of Credit Risk, Liquidity, Capital Adequacy, and Operational Efficiency on Profitability at PT BPD Bali," $E$ Jurnal Manaj. Unud, vol. 4, no 3. ISSN: 2302-8912, 2015.
[11] Parasdita, Khairunnisa, and D. P. K. Mahardika, "The Effect of Internet Banking Adoption, Loan to Deposit Ratio (LDR), Non Performing Loan (NPL), Capitak Adequacy Ratio (CAR), and Operating Expenses and Operating Income (BOPO) on Banking Profitability (Case Study on Banking Companies Listed on Indonesia," e-Proceeding Manag., vol. 5, no 1. ISSN: 2355-9357, 2018.

[12] Soemarsono SR, Accounting is an Introduction, Edition Fi. Jakarta: Salemba Empat, 2004.

[13] M. F. Abdullah, Banking Management (Bank Financial Performance Analysis Technique). Malang: Muhammadiyah Malang University, 2004.

[14] S. Ginting, "Analysis of the Effect of CAR, BOPO, NPM, and LDR on Profit Growth with Interest Rates as a Moderating Variable in Banking Companies Listed on the Indonesia Stock Exchange Period 2013-2016," J. Wira Ekon. Mikroskil, vol. 9, no 1. ISSN: 2622-6421, 2019.

[15] Sudianto, M. Mangantar, and V. Untu, "The Effect of Credit Risk Management, Operational Efficiency, and Capital Adequacy Level on Corparate Profits of Regional Development Banks (BPD) in Eastern Indonesia," J. EMBA, vol. 5, no 3. ISSN: 23031174, 2017. 